\title{
PENERAPAN METODE PEMBELAJARAN MATEMATIKA REALISTIK DALAM MENINGKATKAN HASIL BELAJAR MATEMATIKA PADA SISWA KELAS VI SD NEGERI 163091 TEBING TINGGI
}

\author{
Marlina Naipospos \\ Surel : marlina.nps22@gmail.com
}

\begin{abstract}
This aims to improve math learning achievement through mathematic realistic method. This classroom action researchconducted by 2 cycles of the four phases: planning, implementation, observation, reflection. The subjects were students from class VI, SD N 163091 Tebing Tinggi which amounted to 33 students. This study used a qualitative descriptive analysis technique. The results showed that the used of the mathematic realistic method of math subjects can improve math learning result characterized by increased learning completeness, which occured in first cycle $(78,78 \%)$, cycle II $(90,90 \%)$ and complete learning the clasical equal to 93,93\%.
\end{abstract}

Keywords : Math, Realistic

\begin{abstract}
ABSTRAK
Penelitian ini bertujuan untuk meningkatkan hasil belajar matematika melalui metode matematika realistik. Penelitian tindakan kelas ini dilaksanakan sebanyak 2 siklus dengan empat tahapan yaitu : perencanaan, pelaksanaan, observasi, refleksi. Subjek penelitian ini adalah siswa kelas VI SDN 163091 Tebing Tinggi sebanyak 33 siswa. Penelitian ini menggunakan teknik analisis dekriptif kualitatif. Hasil penelitian menunjukkan bahwa penggunaan metode matematika realistik mata pelajaran matematika dapat meningkatkan hasil belajar siswa yang ditandai dengan peningkatan ketuntasan belajar siswa, yaitu siklus I $(78,78 \%)$, siklus II $(90,90 \%)$ dan dinyatakan berhasil ssecara klasikal 93,93\%.
\end{abstract}

Kata Kunci : Matematika, Realistik

\section{PENDAHULUAN}

Tujuan pendidikan memiliki nilai yang sangat penting dalampembelajaran, seperti yang dikemukakan menurut Hamalik (2008: 80), bahwa tujuan pendidikan memberikan pedoman atau petunjuk kepada guru dalam rangka memilih dan menentukan metode mengajar atau menyediakan lingkungan belajar bagi siswa. Guru berperan menciptakan proses pembelajaran yang aktif dan menyenangkan.

$$
\text { Fungsi pembelajaran }
$$

matematika di sekolah adalah sebagai salah satu unsur masukan instrumental yang memiliki obyek dasar abstrak dan berasaskan kebenaran konsistensi, dalam sistem proses belajar mengajar untuk mencapai tujuan pendidikan. Dengan kata lain, pembelajaran matematika 

merupakan konstruksi dalam bertindak atas dasar pemikiran secara logis, rasional, kritis, jujur dan efektif serta mempersiapkan siswa agar dapat menggunakan matematika dan pola pikir matematika dalam kehidupan sehari-hari dan dalam mempelajari berbagai ilmu pengetahuan (Suharjana, 2009:1).

Menurut

Suherman

(2003:298). Fungsi mata pelajaran matematika sebagai: alat, pola pikir, dan ilmu atau pengetahuan Pembelajaran matematika di sekolah menjadikan guru sadar akan perannya sebagai motivator dan pembimbing siswa dalam pembelajaran matematika di sekolah. NCTM (National Coucil of Teachers of Mathematics) merekomendasikan 4 (empat) prinsip pembelajaran matematika, yaitu: Matematika sebagai pemecahan masalah, Matematika sebagai penalaran, Matematika sebagai komunikasi, dan Matematika sebagai hubungan.

$$
\text { Kurang optimalnya }
$$

pembelajaran matematika di SD Negeri 163091 Tebing Tinggi dapat dilihat dari data pencapaian hasil belajar mata pelajaran matematika padasiswa kelas VI semester II tahun pelajaran 2017/2018, yang secara rata-rata menunjukkan hasil di bawah kriteria ketuntasan minimal (KKM) yang ditetapkansekolah yaitu 60, dari 33 siswa hanya 22 siswa yang tuntas dan 11 siwa yang tidak tuntas. Dengan melihat data hasil belajar dan pelaksanaan pembelajaran tersebut perlu sekali diadakan peningkatan aktivitas belajar agar siswa terlibat aktif dalam pembelajaran sehingga dapat meningkatkan pemahaman siswa terhadap materi pelajaran dan hasil belajar agar siswa kelas VI.

Menurut Heruman (2012: 4), dalam pembelajaran matematika di tingkat SD, diharapkan terjadi reinvention (penemuan kembali). Penemuan kembali adalah menemukan suatu cara penyelesaian secara informal dalam pembelajaran matematika di kelas. Penyelesaian secara informal tersebut dapat dibantu dengan menggunakan media atau alat peraga sehingga dapat meningkatkan kemampuan pola pikir siswa.

Salah satu upaya yang dapat dikembangkan guru adalah dengan Pembelajaran Matematika Realistik (PMR). PMR adalah salah satu pendekatan belajar matematika yang dikembangkan untuk mendekatkan matematika kepada siswa. Masalahmasalah nyata dari kehidupan seharihari digunakan sebagai titik awal pembelajaran matematika untuk menunjukkan bahwa matematika sebenarnya dekat dengan kehidupan sehari-hari.

Menurut Skinner dalam Dimyati dan Mudijono (2009: 9), belajar adalah suatu perilaku. Pada saat orang belajar, maka responsnya menjadi lebih baik. Sebaliknya, bila ia tidak belajar maka responsnya menurun. Aktivitas dapat diterapkan dalam semua kegiatan tatap muka dalam kelas yang terstruktur, baik dalam bentuk komunikasi langsung, 
Marlina Naipospos: Penerapan Metode Pembelajaran ...

kegiatan kelompok dan kegiatan kelompok kecil.

Pembelajaran Matematika

Realistik (PMR) merupakan suatu pendekatan alternatif yang digunakan peneliti untuk meningkatkan atau memperbaikiaktivitas, hasil belajar, dan performansi guru. Menurut Tarigan (2006: 3), PMR menekankan akan pentingnya konteks nyata yang dikenal siswa dan proses konstruksi pengetahuan matematika oleh siswa itu sendiri. Suatu pengetahuan akan menjadi bermakna bagi siswa jika proses pembelajaran dilaksanakan dalam suatu konteks (Wijaya 2012: 20).

Masalah-masalah nyata dari kehidupan sehari- hari digunakan sebagai titik awal pembelajaran matematika untuk menunjukkan bahwa matematika sebenarnya dekat dengan kehidupan sehari- hari. Benda-benda nyata yang akrab dengan kehidupan sehari-hari digunakan sebagai alat peragadalam pembelajaran matematika (Hartono, 2007: 7.1).

Dengan demikian ketika siswa melakukan kegiatan belajar matematika maka dalam dirinya terjadi proses matematisasi atau mematematik akan dunia nyata (Marsigit, 2008).Siswa mencoba menyelesaikan soal-soal kontekstual dari dunia nyata dengan cara mereka sendiri, dan menggunakan bahasa dan simbol mereka sendiri.

Gravemeijer (Supinah, 2008: 16) mengemukakan bahwa terdapat tiga prinsip dalam Pendidikan matematika realistik yaitu sebagai berikut :

a. Guided Re-invention atau Menemukan Kembali Secara Seimbang. Memberikan kesempatan bagi siswa untuk melakukan matematisasi dengan masalah kontekstual yang realistik bagi siswa dengan bantuan dari guru. Siswa didorong atau ditantang untuk aktif bekerja bahkan diharapkan dapat mengkonstruksi atau membangun sendiri pengetahuan yang akan diperolehnya.

b. Didactical Phenomenology atau Fenomena Didaktik. Pembelajaran matematika yang cenderung berorientasi kepada memberi informasi atau memberitahu siswa dan memakai matematika yang sudah siap pakai untuk memecahkan masalah, diubah dengan menjadikan masalah sebagai sarana utama untuk mengawali pembelajaran sehingga memungkinkan siswa dengan caranya sendiri mencoba memecahkannya.

c. Self-delevoped Models atau model dibangun sendiri oleh siswa. Pada waktu siswa mengerjakan masalah kontekstual, siswa mengembangkan suatu model. Model ini diharapkan dibangun sendiri oleh siswa, baik dalam proses matematisasi horisontal ataupun vertikal. 
Tujuan dari penelitian ini adalah untuk meningkatkan hasil belajar matematika pada siswa kelas VI SD Negeri 163091 Tebing Tinggi tahun pembelajaran 2017/2018 melalui metode matematika realistik.

\section{METODE PENELITIAN}

Metode adalah suatu cara yang digunakan untuk memecahkan masalah penelitian. Penelitian ini menggunakan rancangan Penelitian Tindakan Kelas (PTK). Penelitian ini diawali dengan pengajuan judul tentang penelitian yang akan dilaksanakan. Subjek penelitian adalah siswa kelas VI SD Negeri 163091 Tebing Tinggi semester II dengan jumlah siswa sebanyak 33 orang dengan 16 orang laki-laki dan 17orang perempuan. Sumber data yang digunakan adalah siswa dan teman sejawat.

Pada Penelitian tindakan kelas data yang dikumpulkan dapat berbentuk kuantitatif maupun kualitatif. Penelitian tindakan kelas tidak menggunakan uji statistik, tetapi dengan deskriptif. Data kuantitatif yang berupa nilai dianalisis dengan menggunakan analisis deskriptif komparatif yaiu membandingkan nilai tes kondisi awal, nilai tes setelah siklus I dan II yaitu nilai dari hasil ulangan harian siswa kelas VI SD Negeri 163091 pada siklus I dan II. Komponen pengajaran metode matematika realistikyang sangat data kualitatif yang berupa observasi kegiatan guru, dan sisa serta data kuantitatif yang berupa nilai hasil ulangan harian siswa kelas VI.

Penelitian ini adalah penelitian tindakan kelas (PTK) yang terdiri dari 2 siklus. Sesuai dengan jenis penelitian yang dipilih, yaitu penelitian tindakan, maka penelitian ini menggunakan model penelitian tindakan dari Kemmis dan Taggart (dalam Sugiarti, 1997: 6), yaitu berbentuk spiral dari siklus yang satu ke siklus yang berikutnya.

Sebelum
penelitian peneliti mengadakan
rumusan masalah, tujuan dan
membuat rencana tindakan, termasuk
di dalamnya RPP, LKS, observasi,
instrumen penelitian dan perangkat
pembelajaran.

\section{Siklus I}

Siklus I dilakukan pada tanggal 12 Februari 2018. Penerapan inkuiri dilakukan dengan Kegiatan awal melakukan apersepsi, memberikan motivasi dan pengarahan tentang topik yang akan dipelajari. Kegiatan inti yaitu guru memberikan penjelasan untuk pengantar pengamatan mengenai materi ajardengan menjelaskan materi terkait dengan metode matematika realistik. Merumuskan masalah mengenai materi pembelajaran metode matematika realistik. Mengawasi dan memberikan bantuan kepada siswa yang mengalami kesulitan. Pada kegiatan akhir guru memberikan kesimpulan dan melakukan tes evaluasi. 
Marlina Naipospos: Penerapan Metode Pembelajaran ...

Siklus II

Siklus II dilakukan pada tanggal 19 Februari 2018. Siklus II hampir sama dengan siklus I hanya saja pada siklus II ada perbaikan ke arah yang lebih baik. Tindakan pada siklus II ini dilakukan dengan menggunakan paduan perencanaan dan dalam pelaksanaannya bersifat fleksibel serta terbuka terhadap perubahan-perubahan. Guru mengajar dengan menggunakan RPP yang telah disusun dan dipersiapkan sebelumnya. Sedangkan, peneliti dengan bantuan teman mengamati pelaksanaan tindakan dengan menggunakan lembar observasi yang telah dipersiapkan sebelumnya. Kegiatan yang dilakukan pada tahapan ini sama dengan siklus II yaitu terdiri dari kegiatan awal, kegiatan inti dan kegiatan penutup.

Pengamatan dalam proses kegiatan pembelajaran menggunakan metode inkuiri dilakukan oleh peneliti. Kegiatan tersebut dilakukan untuk mengumpulkan data-data yang akan diolah untuk menentukan tindakan yang akan dilaksanakan peneliti selanjutnya. Observasi adalah suatu cara untuk memperoleh data dengan jalan mengadakan pengamatan langsung secara sistematis terhadap suatu objek tertentu yang dicatat dalam catatan observasi (lembar observasi). Pengamatan yang dimaksud adalah pengamatan dengan seluruh alat indera (Arikunto, 1998:128). Pada akhir siklus, peneliti melakukan evaluasi kepada siswa dengan melakukan tes evaluasi.
Peneliti mengkaji, melihat dan mempertimbangkan hasil atau dampak dari tindakan yang dilakukan berdasarkan lembar pengamatan yang diisi oleh pengamat. Tahapan ini dilakukan secara berkesimbungan sehingga ditemukan hasil yang optimal Kegiatan pada tahap refleksi meliputi kegiatan menganalisis, memahami dan membuat kesimpulan berdasarkan hasil observasi setiap siklus. Menemukan kelebihan dan kelemahan tindakan perbaikan pembelajaran. Hasil analisis data yang dilaksanakan pada tahap ini akan dipergunakan untuk menemukan kelebihan dan kelemahan diri dalam merancang dan melakukan tindakan sebagai acuan.

Metode pengumpulan data penelitian ini adalah tertulis dan observasi. Penelitian ini dikatakan berhasil apabila siswa telah memperoleh nilai ketuntasan secara klasikalminimal $85 \%$ dari jumlah siswa dengan rumus sebagai berikut:

Persentase Ketuntasan klasikal =

Jumlah siswa yang tuntas $\quad$ x $100 \%$ Jumlah siswa yang mengikuti tes

\section{HASIL PENELITIAN DAN PEMBAHASAN}

Berdasakan refleksi awal dapat diketahui bahwa dalam pelaksanaan pembelajaran di kelas, penulis menemukan beberapa permasalahan. Permasalahan tersebut antara lain rendahnya keaktifan siswa dalam mengikuti proses pembelajaran di kelas. Hasil 
penelitian tindakan kelas menunjukkan bahwa pengamatan yang dilakukan oleh peneliti dan mitra kolaborasi terhadap hasil belajar matematika metode matematika realistik di kelas VI SD Negeri 163091 Tebing Tinggi dapat dilihat pada Tabel 1 yaitu sebagai berikut:

Tabel 1. Peningkatan Hasil Belajar Siswa Pra Siklus, Siklus I dan II

\begin{tabular}{|c|c|c|c|}
\hline \multicolumn{3}{|c|}{ Peningkatan Hasil Belajar } & \multirow[b]{2}{*}{ Keterangan } \\
\hline $\begin{array}{l}\text { Pra } \\
\text { Siklus }\end{array}$ & $\begin{array}{l}\text { Siklus } \\
\text { I }\end{array}$ & $\begin{array}{l}\text { Siklus } \\
\text { II }\end{array}$ & \\
\hline 22 & 26 & 31 & $\begin{array}{l}\text { Jumlah Siswa } \\
\text { Tuntas }\end{array}$ \\
\hline 70,5 & 76,5 & 82,5 & $\begin{array}{l}\text { Aktivitas } \\
\text { Siswa (\%) }\end{array}$ \\
\hline 71,2 & 73,2 & 75 & Nilai rata-rata \\
\hline 66,67 & 78,78 & 93,93 & $\begin{array}{l}\text { Persentase } \\
\text { Ketuntasan } \\
\text { Belajar (\%) }\end{array}$ \\
\hline
\end{tabular}

Hasil observasi ketrampilan guru pada pembelajaran matematika menggunakan metode pembelajaran matematika realistik dari siklus I ke siklus II. Hasil test pra tindakan menunjukkan bahwa siswa yang tuntas belajar pada pra tindakan sebanyak 22 siswa tuntas belajar dari 33 siswa dengan nilai rata-rata kelas 70,5. siswa. Sebelum dilakukannya metode matematika realistik peneliti mengajarkan materi dengan menggunakan pendekatan pembelajaran konvensional, yaitu pembelajaran berupa informasi verbal yang diperoleh dari buku dan penjelasan peneliti. dilaksanakan dengan 2 siklus.
Hasil observasi keterampilan guru tersebut sebagai penilaian indikator keberhasilan penelitian melalui pendekatan inkuiri untuk meningkatkan kualitas pembelajaran matematika di kelas VI SDN 163091 Tebing Tinggi, kerampilan guru yang diamati pada penelitian ini mengacu pada kegiatan guru saat dikelas. Keterampilan guru yang tampak dalam mempersiapkan pembelajaran dan menciptakan kesiapan mental dan menarik perhatian peserta didik secara optimal agar terpusat sepenuhnya untuk belajar.

Pada kegiatan pembelajaran, guru menugaskan kepada siswa untuk membuat 8 kelompok, masingmasing kelompok beranggotakan 4 dan 5 orang siswa untuk berdiskusi mengenai sifat-sifat bangun ruang. Setiap kelompok diberi berbagai macam benda berbentuk kubus dan balok, model peraga berupa bangun ruang (kubus dan balok) yang terbuat dari karton dan LKS berisi permasalahan yang di gunakan untuk megidentifikasi sifat-sifat bangun ruang. Siswa diberi kesempatan mengamati berbagai benda dan model peraga berbentuk kubus dan balok. Siswa berdiskusi dalam kelompoknya dengan cara mereka masing-masing untuk menyelesaikan masalah yang ada dilembar LKS. Siswa/kelompok yang mengalami kesulitan dibimbing oleh guru.

Pada tahap persiapan, guru menyiapkan masalah/persoalan kontekstual, model dan alat peraga benda-benda real yang berbentuk kubus dan balok yang sering dilihat 
Marlina Naipospos: Penerapan Metode Pembelajaran ...

dalam lingkungan keseharian siswa.Setiap kelompok diberi berbagai macam benda berbentuk kubus dan balok, model peraga berupa bangun ruang (kubus dan balok) yang terbuat dari mika bening dan LKS untuk menggambar bangun ruang kubus dan balok.

Hasil belajar siswan pada siklus I dapat dilihat dari nilai ulangan harian yang diperoleh siswa. Nilai rata-rata kelas pembelajaran siklus I menunjukkan peningkatan bila dibanding dengan pra tindakan, yaitu dari 22 siswa $(66,67 \%)$ yang tuntas belajar menjadi 26 siswa $(78,78 \%)$ pada siklus I. Siswa mengamati berbagai benda berbentuk kubus dan balok serta model peraga yang terbuat dari mika. Media peraga yang disediakan guru menjadi rebutan antar siswa/kelompok karena sebelum pembelajaran guru tidak memberikan instruksi secara jelas mengenai pembagian media peraga.siswa kurang cermat dalam memahami suatu masalah, serta fasilitas alat tulis masih kurang. Siswa berdiskusi dalam kelompoknya dengan cara mereka masing-masing untuk menyelesaikan masalah yang ada dilembar LKS. Siswa/kelompok yang mengalami kesulitan dibimbing oleh guru. Setelah selesai diskusi siswa perwakilan dari kelompok mempresentasikan hasil kerja mereka di depan kelas secara bergantian dengan kelompok lain.Permasalahanpermasalahan yang terjadi pada siklus I kemudian diperbaiki di siklus II.

\section{Pembahasan}

Berdasarkan

hasil

pengamatan guru selama melakukan pembelajaran pada siklus I maka dilakukan perbaikan pada siklus II. Tindakan siklus II dilaksanakan, hasil siklus II terlihat terjadi peningkatan jika dibandingkan dengan hasil yang diperoleh pada siklus I. Ketuntasan belajar siswa pada siklus II meningkat menjadi 31 siswa yang tuntas (93,93\%). Aktivitas siswa pada siklus II juga mengalami peningkatan. Hal tersebut menunjukkan bahwa hasil belajar matematika sudah mencapai target yang ditentukan atau sudah berada diatas indikator yang sudah ditentukan. Berdasarkan hasil yang didapat pada siklus II, baik secara proses maupun tes hasil belajar telah menunjukkan peningkatan dan telah mencapai indikator keberhasilan yang sudah ditetapkan sehingga tidak perlu lagi dilanjutkan ke siklus berikutnya. Secara garis besar kegiatan belajar mengajar dengan metode pembelajaran matematika realistik dilaksanakan terjadi peningkatan ke dalam kategori baik.

Pada saat diskusi berlangsung guru memberikan kesempatan bertanya kepada siswa atau kelompok yang mengalami kesulitan dalam memecahkan masalah dengan cara bertanya kepada teman sesama anggota kelompok atau kepada guru. Pada kesempatan tersebut terlihat beberapa siswa berusaha mencari informasi atau bertanya kepada teman maupun guru untuk 


$\begin{array}{lrl}\begin{array}{l}\text { memecahkan } \\ \text { dihadapinya. }\end{array} & \text { masalah yang } & \begin{array}{l}\text { melibatkan seluruh indera, } \\ \text { pemahaman yang didapat dari }\end{array} \\ \begin{array}{r}\text { Proses } \\ \text { matematika mengenai sifat-sifat }\end{array} & \begin{array}{l}\text { pembelajaran } \\ \text { bangun ruang sederhana mengalami }\end{array} \\ \begin{array}{l}\text { keningkatan. Hal tersebut terlihat } \\ \text { dari hasil observasi terhadap }\end{array} & \begin{array}{l}\text { ketuntasan belajar yang diperoleh } \\ \text { setelah melakukan penelitian dengan }\end{array} \\ \text { aktivitas siswa dan guru pada siklus I } & \text { pada diagram berikut: }\end{array}$
dan siklus II yang meningkat. Meningkatnya hasil belajar siswa tersebut disebabkan pendekatan pendidikan matematika realistik mampu membuat siswa mengalami secara langsung proses pembelajaran. Hal tersebut sejalan dengan teori yang diungkapkan Tarigan (2006:3) bahwa Pembelajaran Matematika Realistik (PMR) merupakan suatu pendekatan alternatif yang digunakan peneliti untuk meningkatkan atau memperbaiki aktivitas, hasil belajar, dan performansi guru. pembelajaran matematika realistik menekankan akan pentingnya konteks nyata yang dikenal siswa dan proses konstruksi pengetahuan matematika oleh siswa itu sendiri.

Selain itu, Hartono (2007: 7.1) menyebutkan bahwa bendabenda nyata yang akrab dengan kehidupan sehari-hari digunakan sebagai alat peragadalam pembelajaran matematika. Pendekatan pendidikan matematika realistik mampu membuat siswa mengalami secara langsung proses pembelajaran. pengalaman langsung memberikan kesan paling utuh dan paling bermakna mengenai informasi dan gagasan yang terkandung dalam pembelajaran karena hampir

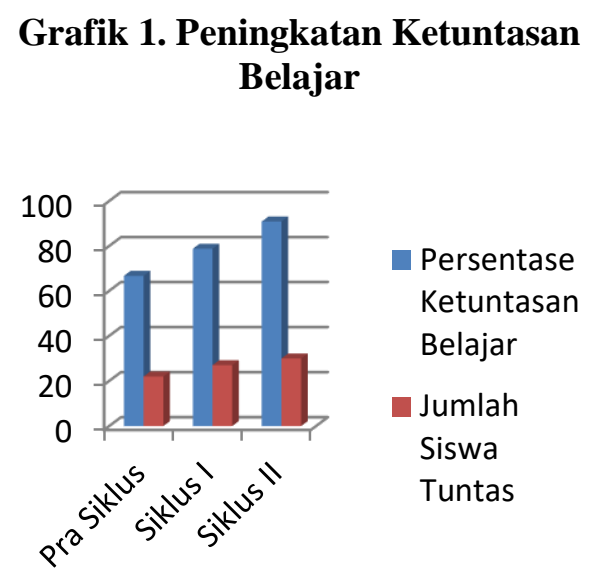

Dengan melihat indikator yangt telah ditetapkan sebelumnya, hasil yang diperoleh telah mencapai lebih dari batas minimal indikator keberhasilan sehingga penelitian tidak perlu dilanjutkan lagi untuk siklus berikutnya. Oleh karena itu dapat disimpulkan bahwa proses pembelajaran dengan penerapan penemuan terbimbing sangat sesuai dengan mata pelajaran matematika, maka Penelitian Tindakan Kelas (PTK) ini bisa dikatakan berhasil karena hasil peningkatan proses pembelajarannya optimal.

\section{SIMPULAN}

Dari hasil temuan penelitian tentanghasil belajar siswa dengan metode penemuan terbimbing di kelas VI SD Negeri 163091 Tebing 
Marlina Naipospos: Penerapan Metode Pembelajaran ...

Tinggi tahun pelajaran 2017/2018 berdampak positif dalam meningkatkan keterampilan guru dan hasil belajar siswa setiap siklusnya. Penerapan strategi pembelajaran matematika realistik. Peningkatan hasil dan aktivitas pembelajaran menggunakan pendekatan matematika realistik yaitu siswa sudah aktif untuk bertanya dan mencari informasi serta siswa juga sudah memiliki rasa tanggungjawab dengan tugasnya masing-masing menentukan hipotesis, membuat siswa berani bertanya, menjawab, dan mengajukan gagasan. Selain itu juga telah mengaktifkan siswa dalam proses diskusi. Hal tersebut dapat dilihat dari peningkatan persentase ketuntasan belajar siswa pada siklus I $(78,78 \%)$, siklus II $(93,93 \%)$ dan dinyatakan berhasil.

Atas dasar simpulan dan implikasi hasil penelitian tindakan kelas di atas, penulis memberikan saran-saran sebagai berikut :

a. Bagi Guru Dalam menggunakan PMR, sebaiknya guru menggunakan media/alat peraga yang dekat dengan kehidupan sehari-hari siswa dan mengenalkan konsep matematika yangabstrak melalui benda nyata dan masalah kontekstual.

b. Bagi Siswa diharapkan terlibat secara aktif dalam proses belajar mengajar, hal ini akan mempermudah tercapainya tujuan belajar.

\section{DAFTAR RUJUKAN}

Dimyati dan Mudjiono. 2006. Belajar dan Pembelajaran. Jakarta : Rineka Cipta.

Hamalik. 2008. Kurikulum dan Pembelajaran. Jakarta: Bumi Aksara

Heruman. 2012. Model Pembelajaran Matematika di Sekolah Dasar. Bandung: Remaja Rosdakarya.

Hartono, Y. 2007. Pengembangan Pembelajaran Matematika. Jakarta: Dirjendikti Depdiknas.

Suherman, E.dkk. 2003. Strategi Pembelajaran Matematika Kontemporer. Bandung : PT. Remaja Rosdakarya.

Supinah. 2008. Pembelajaran Mtematika SD dengan Pendekatan kontekstual dalam Melaksanakan KTSP. Yogyakarta: PPPPTK Matematika.

Tarigan, Daitin. 2006. Pembelajaran Matematika Realistik. Jakarta: DEPDIKNAS DIRJENDIKTI Direktorat Ketenagaan.

Suharjana, A.,dkk. 2009. Geometri Dasar dan ruang di SD. Sleman : Depdiknas

Wijaya, Ariyadi. 2012. Pendidikan Matematika Realistik Suatu Alternatif Pendekatan Pembelajaran Matematika. Yogyakarta: Graha Ilmu. 